\title{
THE IMPACT OF CLIMATE CHANGE ON VITICULTURAL POTENTIAL AND WINE GRAPE VARIETIES OF A TEMPERATE WINE GROWING REGION
}

\author{
IRIMIA, L. M. ${ }^{1 *}-$ PATRICHE, C. V. ${ }^{2}-$ MURARIU, O. C. ${ }^{1}$ \\ ${ }^{1}$ Faculty of Horticulture, University of Agricultural Sciences and Veterinary Medicine "Ion \\ Ionescu de la Brad” Iași, 3, Mihail Sadoveanu Alley, 700490 Iaşi, Romania \\ (phone: +40-232-407-407; fax: +40-232-260-650) \\ ${ }^{2}$ Geography Group, Iaşi Branch, Romanian Academy, 8, Carol I Street, 700505 Iasi, Romania \\ (phone: +40-232-211-150) \\ *Corresponding author \\ e-mail: liviuirimia2005@yahoo.fr; phone: +40-232-407-346
}

(Received $14^{\text {th }}$ Jan 2018; accepted $16^{\text {th }}$ Apr 2018)

\begin{abstract}
Climate change causes major shifts in both the spatial distribution of wine-growing areas and their specific types of wine production. With the increase of heliothermal resources, the viticultural potential of temperate wine regions grows, becoming more suitable for quality wine production and for the diversification of the wine types production. The shifts in the viticultural potential of the Averești wine-growing region from Romania during the last decades are evidence of these evolutions. Between 1961-2013, the average annual temperature in the area increased by $0.47{ }^{\circ} \mathrm{C}$, the temperature of July by $1.26{ }^{\circ} \mathrm{C}$, the sunshine duration by $78.6 \mathrm{~h}$ and the global radiation by $1.69 \mathrm{kcal} / \mathrm{cm}^{2}$. Against this background, the area passed from viticultural potential mainly for white table wines to viticultural potential for quality white wines and red table wines. The new viticultural potential is exploited in the Averesti wine-growing region after 2000 by expanding into culture the international winegrape varieties for quality white wines and by introducing the Cabernet Sauvignon, Merlot and Pinot noir winegrape varieties for red wines into cultivation. The study demonstrates the need to evaluate the new viticultural potential generated by climate change and the need to delineate the viticultural homogeneous zones in the wine-growing regions beneficiary of climate change, in order to correctly zone newly introduced winegrape varieties in such areas.
\end{abstract}

Keywords: grapevine, viticulture, Averești, wine, suitability

\section{Introduction}

The specific varieties of wine-growing regions have been established throughout the time by maintaining in their area the winegrape varieties best suited to local relief, climate and soil conditions. These environmental factors have a decisive influence on grapevine growing and fruiting (van Leeuwen and Seguin, 2006; Winkler et al., 1974). In relation to the influence of the climate, winegrape varieties whose grapes reach full ripening each year and which best express their quality potential have been maintained (Seguin, 1986). As a result, today each wine-growing region has its own specific winegrape varieties best adapted to the local environment and which provide the most qualitative wines that can be obtained in the area (Wolkovich et al., 2018).

Due to this close dependence of winegrape varieties on the climate, one of the consequences of climate change (IPCC, 2013) might be their modification and implicitly, the one of the types of wine production specific to affected wine-growing regions. The first predictions in this regard have been made since the 1990s by Kenny and Harrison (1992), and confirmations of this evolution appear more and more 
frequent in recent years (Stock et al., 2005; Bucur and Dejeu, 2016; Irimia et al., $2017 \mathrm{~b}$ ). The modification of wine-growing regions' specific winegrape varieties is, in fact, an adaptation of wine-growing regions to the new climatic context, with particularities from one geographic area to another. For example, in case of the Mediterranean wine-growing regions, where high temperatures already affect the wellestablished sensory profile of wines (Nemani et al., 2001), it might be necessary to replace local varieties with some more adapted to the warm climate ones (Wolkovich et al., 2018). On the contrary, in cool vineyards where the climate becomes more suitable to viticulture (Gaal et al., 2012; Kryza et al., 2015; Nesbitt et al., 2016; Kovacs et al., 2017; Irimia et al., 2017a) varieties for white table wines, could be replaced by varieties for quality white wines and even by varieties for red wines.

In the context of climate change (Busuioc et al., 2010; Piticar and Ristoiu, 2012; Dumitrescu et al., 2014; Bandoc et al., 2018) recent studies indicate that Romania's viticulture undergoes structural and spatial changes of climatic suitability for viticulture (Bucur and Dejeu, 2016; Irimia et al., 2017a). Climatic suitability for red wines is advancing from $\mathrm{S}$ to $\mathrm{N}$, overlapping traditional white wine production areas; climate suitability for white wines is advancing northwards and at higher altitudes, beyond the limits of traditional wine-growing areas. Significant shifts are also recorded in vineyards on a fine scale (Irimia et al., 2017b).

As a result of this evolution of climatic suitability for viticulture, the traditional varieties of vineyards in the northern part of Romania, which is colder, have begun to undergo important changes: In the vineyards of Transylvania, a wine-growing region specialised in white wine production, Pinot noir, Merlot and the native Fetească neagră red varieties have recently been introduced (Urcan et al., 2016), while in the vineyards of Moldavia, also producing white wines, Cabernet Sauvignon, Merlot, Pinot noir and Feteasca neagră have been introduced.

The purpose of this study is to reveal the changes in viticultural potential as a result of climate change in the Averești wine-growing region, as well as the changes in its specific winegrape varieties in this context. Previous studies have already revealed the suitability of this area for white wine production (Irimia and Patriche, 2009, 2010). On the background of climatic change, after 2000 winegrape varieties such as Cabernet Sauvignon, Merlot, Pinot noir and Feteasca neagră were introduced in the area. For the accumulation of anthocyanins and the production of quality wines, winegrape varieties for red wine require high heliothermal resources (Dokoozlian and Kliewer, 1996). The location of the new red winegrape varieties in the Averești area was not based on a zoning study, which is why this study aims to evaluate the accuracy of their zoning. Inadequate location of a winegrape variety in a vineyard limits the expression of its qualitative potential and produces ordinary wines (Asselin et al., 2001; Riou et al., 1994).

Assessment of the viticultural potential is based on the analysis of the spatial distribution and suitability for the winegrape varieties of the climate, relief and soil factors (Jones and Duff, 2007; Tomasi et al., 2013; Irimia et al., 2014; Nowlin and Bunch, 2016). Studies based on bioclimatic indices (Blanco-Ward et al., 2017; Quenol et al., 2017), soil and lithological parameters (Morlat and Bodin, 2006) and their combined influence (Jacquet and Morlat, 1997) are also used. This study uses the GISbased methodology for assessing the viticultural potential in temperate climate conditions of Romania (Irimia et al., 2014), which takes into account the fine-scale 
spatial distribution and the suitability for winegrape growing of 15 parameters representative for vineyards' relief, soil and climate.

The study is designed in four parts, namely: the structure and suitability of the relief, soils and climate in the area; the viticultural potential and the specific winegrape varieties during 1961-1979; the viticultural potential of the 1981-2013 period and the current winegrape varieties; the analysis of the current location of winegrape varieties in the area.

\section{Materials and methods}

\section{Study area}

The study area is the Avereşti wine-growing region, located in the eastern part of Romania, at 46 46'50" N latitude and $28^{\circ} 0^{\prime} 37^{\prime \prime}$ E longitudes (Fig. 1).

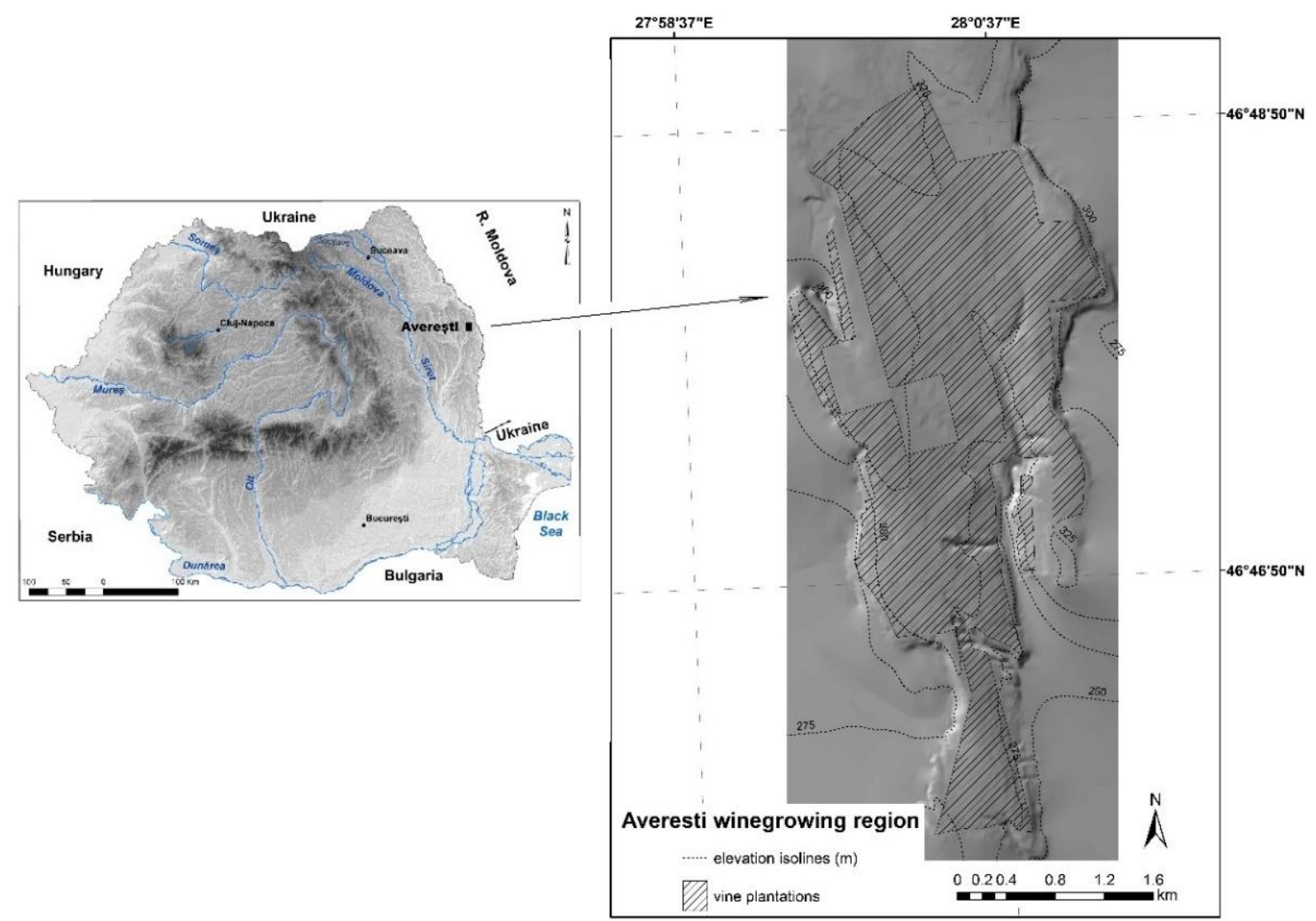

Figure 1. The map of the Averești wine-growing region and its geographical location

The area has a surface of about 670 ha and it is a compact massive vineyard, situated on a long interfluvial plateau, bordered by river valleys in the east and west and having a slope which causes a difference of about $80 \mathrm{~m}$ between the northern $(338 \mathrm{~m}$ asl elevation) and the southern limit $(257 \mathrm{~m}$ asl). The area has a temperate continental climate, Dfb in the Koppen-Geiger climate classification (Kottek et al., 2006), with warm and sometimes dry summers, and harsh and sometimes frosty winters. Soils are predominantly represented by Luvisols, with a higher content of clay and humus in the plateau area and thinner, poorly fertile and well drained on east and west slopes. 


\section{Methods}

The climate data used for this study were extracted from ROCADA database (Dumitrescu and Bîrsan, 2015) for one point situated in the middle of the vineyard (46 $47^{\prime} 94^{\prime \prime} \mathrm{N}$ latitude, $28^{\circ} 0^{\prime}$ 21.6" E longitude, $303.59 \mathrm{~m}$ asl). For this location, we extracted daily values of climate parameters, including the mean, maximum and minimum temperatures, precipitations, sunshine duration and relative humidity. The values were exported in Excel for quality check and processing. The spatialization of these punctual data was achieved in GIS environment, starting from a $5 \times 5 \mathrm{~m}$ digital elevation model (DEM) and vertical temperature and precipitation gradients (Patriche et al., 2011). The DEM was computed with high accuracy, on the basis of the elevation information extracted from 1:5000 topographic maps. The mean annual and monthly vertical gradients for temperature and precipitations were derived from WorldClim database (Hijmans et al., 2005) and SRTM elevation model for the entire Romanian territory.

The potential solar radiation and sunshine duration maps were computed in SAGAGIS 2.0.8, using the Incoming Solar Radiation module and DEM as input raster. A correction was then applied to the potential global radiation (Entekhabi, 1997), based on the sunshine fraction, in order to achieve the actual global radiation. The actual sunshine duration was derived by multiplying the potential sunshine duration and the sunshine fraction.

The bioclimatic indices were achieved in GIS environment by applying the specific formulas (Irimia et al., 2014).

The terrain slope and aspect were derived based on DEM, and the respective rasters were classified according to the methodology.

For soil cover characterization, we used the data from 11 soil profiles taken from a fine scale agrochemical study of Averești vineyard. The clay content was interpolated by ordinary kriging, while in the case of humus content a spline interpolation was performed. Then, the spatial distributions and clay and humus contents were classified according to the methodology. The analysed soils from Averești vineyard had no skeleton content in the first $50 \mathrm{~cm}$.

The viticultural potential of the area was assessed using Irimia et al. (2014) methodology for viticultural potential assessment in Romanian wine-growing regions conditions. According to this method, the averages of 15 climatic, pedological and topographical parameters for the Averești area for two time periods (1961-1979 and 1980-2013) were mapped and then classified into three suitability classes, ranked from 5 to 10 points (Table 1). What is more, the values within the range defined by each suitability class determine and characterize under the temperate continental climate of Romania, a certain type of wine production (Irimia et al., 2014). The choice of the two periods is based on a previous study (Irimia et al., 2017b), which points out that the warming process began consistently in the 1980's for the neighbouring wine-growing region of Cotnari (Romania). Also, the charts made up at Global and European level (EEA, 2017) show that the beginning of abrupt temperature change occurred during the same time period.

The spatial information layers for each ecological category and for each time period were further combined into a GIS database, and the average ranking points (arp) at the pixel level $(5 \times 5 \mathrm{~m})$ were calculated in order to obtain topographical, pedological and climate suitabilities. The three maps of suitability for each time period were further combined into a GIS database, and the average of ranking points at the pixel level $(5 \times 5$ 
m) was calculated in order to obtain the viticultural potential. According to this methodology, the averages of ranking points have the following meanings (Table 2): 5 $\operatorname{arp}=$ viticultural potential for white table wines, sparkling wines and wines for distillates (WTW, SW, WD); 6 arp = viticultural potential for white table wines, sparkling wines, wines for distillates as well as for white quality wines in warmer growing seasons (WTW, SW, WD + QWW); 7 arp = viticultural potential for quality white wines $(\mathrm{QWW}) ; 8$ arp = viticultural potential primarily for quality white wines and secondarily for red table wines (QWW + RTW); 9 arp = viticultural potential primarily for quality red wines and secondarily for quality white wines (QRW + QWW); 10 arp = viticultural potential for quality red wines (QRW). The 10 arp and 9 arp were grouped into class I - QRW; 8 arp and 7 arp into class II - QWW; 6 arp and 5 arp into class III WTW, SW, WD; and the pixels where restrictive values appeared were classified as class IV, as unsuitable for wine production (Table 2).

Table 1. Ecological factors and bioclimatic indices ranked according to their suitability for different types of wine production in temperate continental climatic conditions of Romanian wine-growing regions (according to Irimia et al., 2014)

\begin{tabular}{|c|c|c|c|c|c|c|}
\hline \multirow{4}{*}{$\begin{array}{c}\text { Ecological } \\
\text { category }\end{array}$} & \multirow{4}{*}{$\begin{array}{c}\text { Parameters } \\
\text { (abbreviation } \\
\text { units) }\end{array}$} & \multirow{4}{*}{$\begin{array}{c}\text { Suitability } \\
\text { interval } \\
\text { within } \\
\text { Romanian } \\
\text { winegrowing } \\
\text { regions }\end{array}$} & \multirow{4}{*}{$\begin{array}{c}\text { Unsuitable } \\
\text { IV/0 } \\
\text { Restrictive } \\
\text { for } \\
\text { grapevine } \\
\text { growing }\end{array}$} & \multicolumn{3}{|c|}{ Suitability classes/ranking points } \\
\hline & & & & III/5 & II/8 & $\mathbf{I} / \mathbf{1 0}$ \\
\hline & & & & \multicolumn{3}{|c|}{ Type of wine production ${ }^{* *}$} \\
\hline & & & & $\begin{array}{c}\text { WTW, SW, } \\
\text { WD }\end{array}$ & QWW & QRW \\
\hline \multirow{2}{*}{$\begin{array}{c}\text { Topographical } \\
\text { factors }\end{array}$} & $\mathrm{S}(\%)$ & $0-28$ & - & $<8$ & $>15$ & $8-15$ \\
\hline & A & - & - & $\mathrm{NW}, \mathrm{N}, \mathrm{NE}$ & $\mathrm{E}, \mathrm{W}$ & SE, S, SW \\
\hline \multirow{10}{*}{$\begin{array}{c}\text { Climatic factors } \\
\text { and bioclimatic } \\
\text { indices }\end{array}$} & AAT $\left({ }^{\circ} \mathrm{C}\right)$ & $8.5-11.2$ & $<8.5$ & $8.5-9.3$ & $9.4-10.0$ & $10.1-11.2$ \\
\hline & $\mathrm{TWM}\left({ }^{\circ} \mathrm{C}\right)$ & $18.0-22.0$ & $<18.0$ & $18.1-19.7$ & $19.8-21.0$ & $21.1-22.0$ \\
\hline & $\mathrm{GR}\left(\mathrm{kcal} / \mathrm{cm}^{2}\right)$ & $80.0-92.0$ & $<80.0$ & $80-83.9$ & $84.0-86.9$ & $87.0-92.0$ \\
\hline & ASD (hours) & $1280-1610$ & $<1280$ & $1280-1450$ & $1451-1550$ & $1551-1610$ \\
\hline & $\mathrm{PP}(\mathrm{mm})$ & $250-390$ & - & $>390$ & $<250$ & $251-390$ \\
\hline & $\Sigma \mathrm{t}_{\mathrm{u}}\left({ }^{\circ} \mathrm{C}\right)$ & $1045-1675$ & $<1045$ & $1045-1200$ & $1201-1400$ & $1401-1675$ \\
\hline & LGS (days) & $160-210$ & $<160$ & $160-175$ & $176-190$ & $>190$ \\
\hline & Iha & $1.36-2.66$ & $<1.36$ & $1.36-1.70$ & $1.71-2.20$ & $2.21-2.66$ \\
\hline & Ibcv & 3.9-13.0 & $<3.9$ & $3.9-5.0$ & $5.1-8.0$ & $8.1-13.0$ \\
\hline & IAOe & $3793-4600$ & $<3793$ & $3793-4300$ & $4301-4600$ & $>4600$ \\
\hline \multirow{3}{*}{$\begin{array}{l}\text { Pedological } \\
\text { factors }\end{array}$} & Cly $(\%)$ & $6-40$ & $>40.0$ & $<15$ & $25-40$ & $15-25$ \\
\hline & Hum $(\%)$ & $1.5-4.0$ & - & $3.1-4.0$ & $2.1-3.0$ & $1.5-2.0$ \\
\hline & Gra $(\%)$ & $0-40$ & $>40.0$ & $<10$ & $30-40$ & $10-30$ \\
\hline
\end{tabular}

${ }^{*} S=$ slope; $A=$ terrain aspect; $A A T=$ annual average temperature; $T W M=$ warmest month temperature; $G R=$ global radiation; $A S D=$ actual sunshine duration; $P P=$ precipitation during the growing season; $\Sigma t_{u}=$ sum of effective temperatures; $L G S=$ length of the growing season; Iha = actual heliothermal index; Ibcv = bioclimatic index Constantinescu; IAOe = oenoclimate aptitude index; Cly = clay; Hum = humus; $G r a=$ gravel

${ }^{* *} W T W, S W, W D=$ white table wines, sparkling wines and wines for distillates; $Q W W=$ quality white wines; $Q R W=$ quality red wines 
Table 2. Characterizing viticultural potential according to the average of ranking points (arp) (Irimia et al., 2014)

\begin{tabular}{c|c|c}
\hline Class & $\begin{array}{c}\text { Average of ranking } \\
\text { points (arp) }\end{array}$ & Viticultural potential of the area \\
\cline { 2 - 3 } I & 10 & Viticultural potential for quality red wines (QRW) \\
\cline { 2 - 3 } II & 9 & $\begin{array}{c}\text { Viticultural potential primarily for quality red wines and secondarily } \\
\text { for quality white wines (QRW + QWW) }\end{array}$ \\
\cline { 2 - 3 } & 8 & $\begin{array}{c}\text { Viticultural potential primarily for quality white wines and } \\
\text { secondarily for red table wines (QWW + RTW) }\end{array}$ \\
\hline \multirow{3}{*}{ III } & 6 & $\begin{array}{c}\text { Viticultural potential for quality white wines (QWW) } \\
\text { Viticultural potential for white table wines, sparkling wines, and } \\
\text { wines for distillates, as well as for quality white wines in very } \\
\text { suitable years, in terms of climate (WTW, SW, WD + QWW) }\end{array}$ \\
\cline { 2 - 3 } & 5 & $\begin{array}{c}\text { Viticultural potential for white table wines, sparkling wines, and } \\
\text { wines for distillates (WTW, SW, WD) }\end{array}$ \\
\hline IV & 0 & Unsuitable for grape growing (UNS) \\
\hline
\end{tabular}

The accuracy of the current winegrape varieties zoning was carried out by comparative analysis of the red varieties plots location with the viticultural potential of the area in which they are situated. In the case of red winegrape varieties, we assed the framing of their plots into areas with viticultural potential for RTW; and in the case of white wine varieties, we assed their framing into areas suitable for QWW and RTW.

\section{Results}

\section{Structure and suitability of topography, soils and climate of the studied area}

The Avereşti winegrowing region is situated in a hilly area with an important variation of the slope and of terrain aspect (Fig. 2). The slope varies between 0 and $45 \%$, with a predominance of $<8 \%$ on about $80 \%$ of the area (Fig. $2 a$ ), while the terrain aspect is represented by all types, from those unsuitable for grapevine growing such as the northern ones to the very suitable ones like south (Fig. 2b). However, the eastern terrain aspect is predominant in the area by $38.6 \%$, followed by northeastern by $11.2 \%$ and by southern and southeastern by about $9 \%$.

Spatial variation of the slope and of the terrain aspect make the Avereşti area present all topographical suitability classes for wine production, were classes III and II are predominant (Fig. 3 and Table 3): class III, suitable for WTW, SW and WD, characterizes $50 \%$ of the area, while class II, suitable for QWW, characterizes $35.6 \%$ of the area. $14 \%$ of the surface is characterized by class I of topographic suitability (QRW), and by slopes of 8-15\% inclination with southern and predominantly southern terrain aspects.

Regarding the pedological suitability, the whole area is characterized by class II, suitable for QWW, of which 66\% has an average of 7 arp (QWW), and 34\% has an average of 8 arp (QWW + RTW) (Fig. 3 and Table 3). Pedological suitability is given by the low humus content, ranging from 0.14 to $1.99 \%$ (class I) for $100 \%$ of the area; lack of limestone fragments from soils (class III) on $100 \%$ of the surface; and a clay content of $14-29 \%$ (class II) for $100 \%$ of the area. The low humus content of the soil is a factor that favours grape quality and is not restrictive when it falls below $1.5 \%$ because it is corrected by fertilization. 


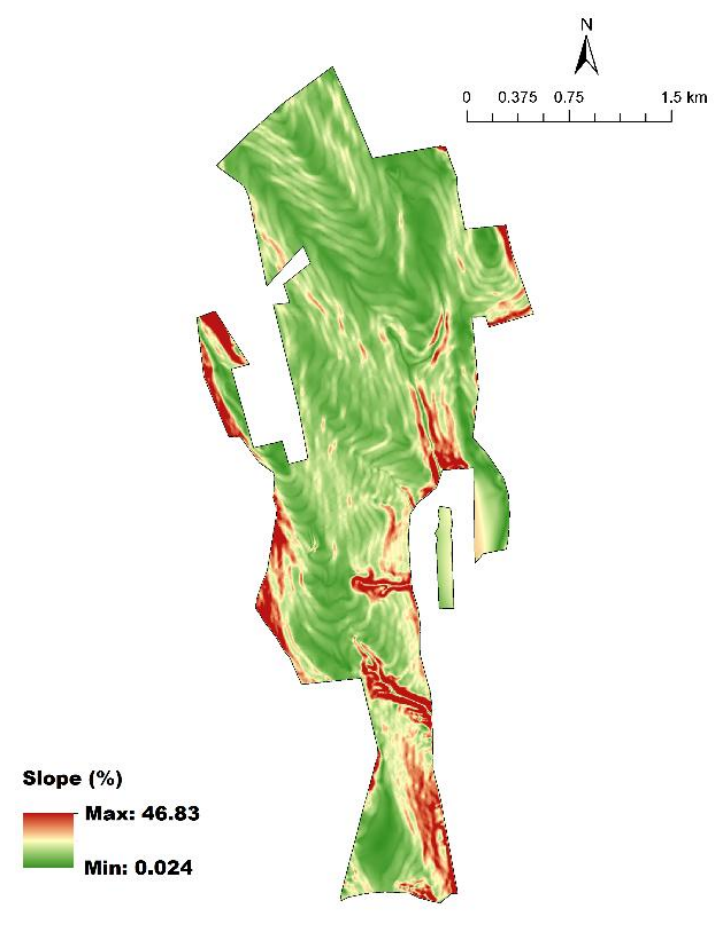

a

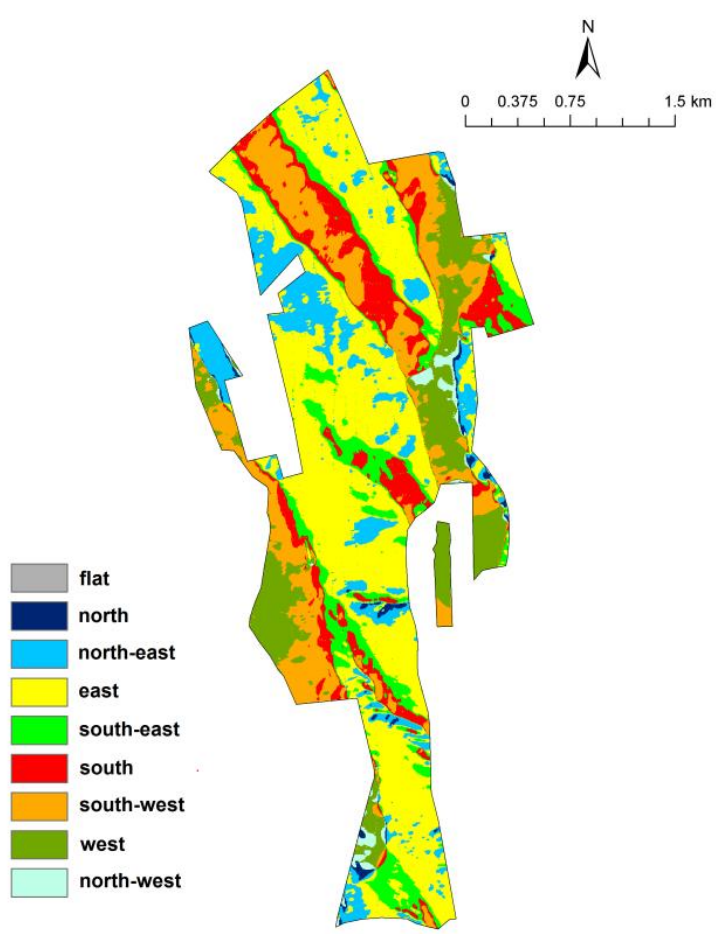

b

Figure 2. Slope (a) and terrain aspect (b) in the Averești wine-growing region

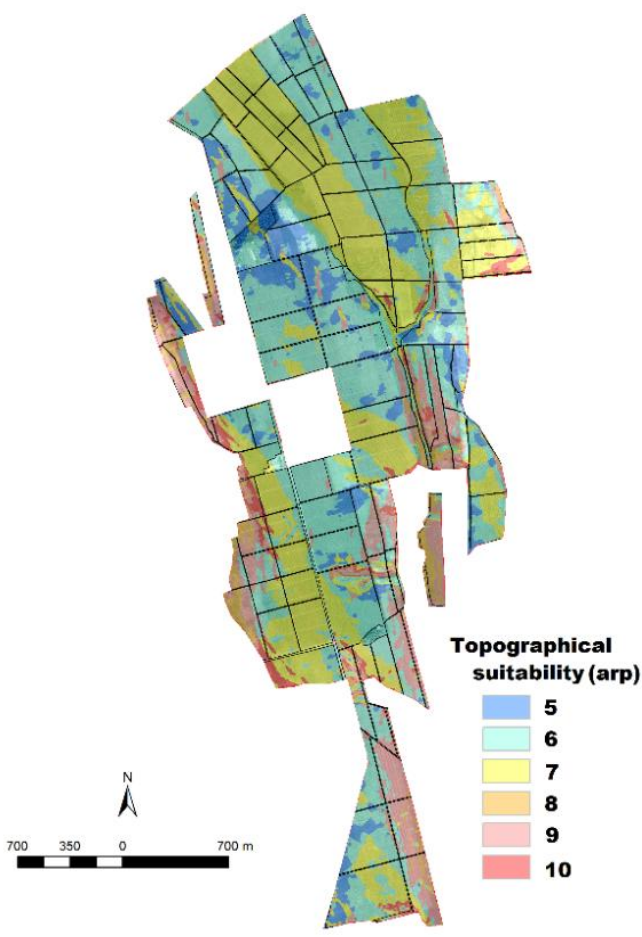

a

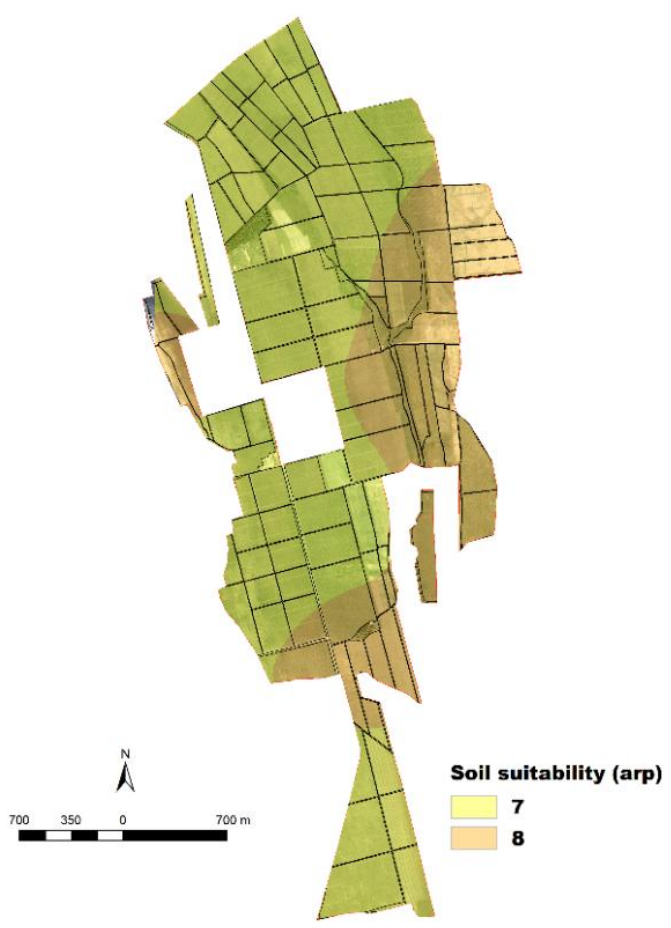

b

Figure 3. Topographical (a) and pedological suitability (b) for the Averești wine-growing region 
Table 3. Structure of the topographical and pedological suitability for wine production in the Averești wine-growing region, during the 1961-2013 time period

\begin{tabular}{|c|c|c|c|c|c|c|c|}
\hline \multicolumn{4}{|c|}{ Topographical suitability } & \multicolumn{4}{|c|}{ Pedological suitability } \\
\hline \multirow{2}{*}{ Class } & \multirow{2}{*}{$\operatorname{arp}$} & \multicolumn{2}{|c|}{ Share for 1961-2013 } & \multirow{2}{*}{ Class } & \multirow{2}{*}{ arp } & \multicolumn{2}{|c|}{ Share for 1961-2013 } \\
\hline & & ha & $\%$ & & & ha & $\%$ \\
\hline \multirow{2}{*}{ III } & 5 & 71.2 & 10.6 & \multirow{2}{*}{ III } & 5 & 0.0 & 0.0 \\
\hline & 6 & 265.6 & 39.4 & & 6 & 0.0 & 0.0 \\
\hline \multirow{2}{*}{ II } & 7 & 220.2 & 32.7 & \multirow{2}{*}{ II } & 7 & 443.4 & 66.0 \\
\hline & 8 & 21.1 & 3.1 & & 8 & 228.9 & 34.0 \\
\hline \multirow{2}{*}{ I } & 9 & 76.9 & 11.4 & \multirow{2}{*}{ I } & 9 & 0.0 & 0.0 \\
\hline & 10 & 19.2 & 2.9 & & 10 & 0.0 & 0.0 \\
\hline \multicolumn{2}{|c|}{ Total } & 674.3 & 100.0 & \multicolumn{2}{|c|}{ Total } & 672.2 & 100.0 \\
\hline
\end{tabular}

While relief and soils are stable ecological factors that do not cause temporal variations in the quality of wine production, climate is the factor that determines both spatial and temporal variation (Le Roux et al., 2017). In the case of Avereşti winegrowing region, the changes caused by the climate change in climate suitability for wine production between 1961 and 2013 are obvious in the data from Table 4 and in the maps in Figure 4.

Table 4. Structure of climate suitability for wine production in the Averești wine-growing region, for the 1961-1979 and 1980-2013 time periods

\begin{tabular}{|c|c|c|c|c|c|c|c|}
\hline \multicolumn{4}{|c|}{ Climate suitability 1961-1979 } & \multicolumn{4}{|c|}{ Climate suitability 1980-2013 } \\
\hline \multirow{2}{*}{ Class } & \multirow{2}{*}{$\operatorname{arp}$} & \multicolumn{2}{|c|}{ Share } & \multirow{2}{*}{ Class } & \multirow{2}{*}{$\operatorname{arp}$} & \multicolumn{2}{|c|}{ Share } \\
\hline & & ha & $\%$ & & & ha & $\%$ \\
\hline \multirow{2}{*}{ III } & 5 & 8.9 & 1.3 & \multirow{2}{*}{ III } & 5 & 0.0 & 0.0 \\
\hline & 6 & 665.4 & 98.7 & & 6 & 1.7 & 0.2 \\
\hline \multirow{2}{*}{ II } & 7 & 0.0 & 0.0 & \multirow{2}{*}{ II } & 7 & 434.5 & 64.4 \\
\hline & 8 & 0.0 & 0.0 & & 8 & 238.2 & 35.3 \\
\hline \multirow{2}{*}{ I } & 9 & 0.0 & 0.0 & \multirow{2}{*}{ I } & 9 & 0.0 & 0.0 \\
\hline & 10 & 0.0 & 0.0 & & 10 & 0.0 & 0.0 \\
\hline \multicolumn{2}{|c|}{ Total } & 674.3 & 100 & \multicolumn{2}{|c|}{ Total } & 672.2 & 100 \\
\hline
\end{tabular}

Between 1961 and 1979, 100\% of the Avereşti wine-growing region was characterized by climate suitability for WTW, SW, WD and for QWW in the warm growing season (Table 4). This reduced climatic suitability is due to low values of heliothermic factors (Table 5): AAT of $8.47{ }^{\circ} \mathrm{C}$, below the lower limit for the economical cultivation of wine varieties; $\Sigma \mathrm{t}_{\mathrm{u}}$ of $1110{ }^{\circ} \mathrm{C}$, value at the lower limit of suitability for wine production; ASD of $1447 \mathrm{~h}$, sufficient only for the production of white wines; LGS of 172 days, sufficient only for early winegrape varieties; IAOe of 4178 units, sufficient only for the production of white wines. 


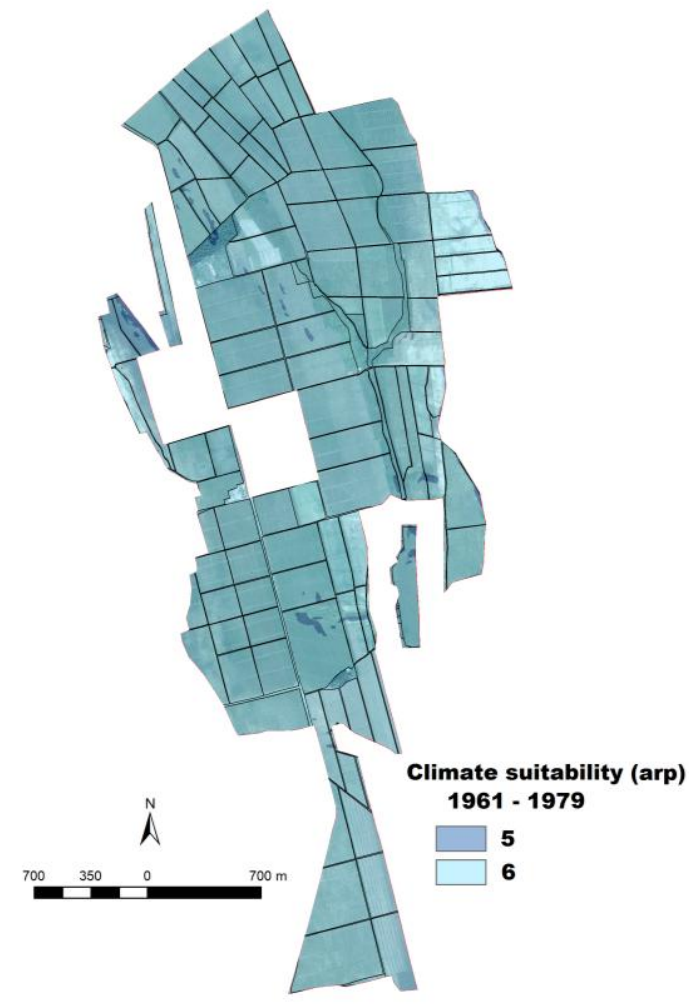

a

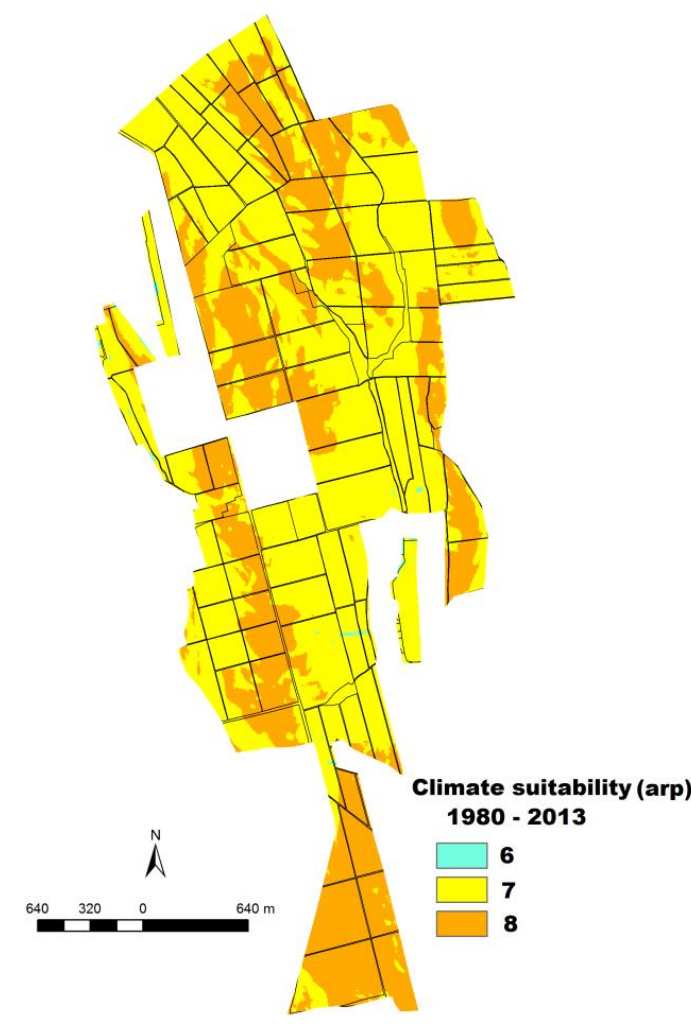

b

Figure 4. Climate suitability for the 1961 to 1979 (a) and for the 1980 to 2013 time period (b) for the Averești wine-growing region

Table 5. Statistics on climate parameters defining climate suitability for the wine production in the Averești wine-growing region, for the 1961-1979 and the 1980-2013 time periods

\begin{tabular}{c|c|c|c|c|c|c|c|c}
\hline \multirow{2}{*}{ Parameter } & \multicolumn{5}{|c|}{ 1961-1979 } & \multicolumn{4}{|c}{$\mathbf{1 9 8 0 - 2 0 1 3}$} \\
\cline { 2 - 9 } & Mean & Min & Max & Range & Mean & Min & Max & Range \\
\hline AAT & 8.47 & 8.31 & 8.72 & 0.40 & 8.94 & 8.79 & 9.19 & 0.40 \\
WMT & 19.46 & 19.27 & 19.77 & 0.50 & 20.72 & 20.53 & 21.03 & 0.50 \\
GR & 88.79 & 72.99 & 96.10 & 23.12 & 90.48 & 74.37 & 97.93 & 23.55 \\
ASD & 1447.72 & 1245.95 & 1501.97 & 256.02 & 1526.30 & 1313.58 & 1583.49 & 269.91 \\
PP & 347.63 & 338.10 & 353.45 & 15.34 & 333.51 & 323.98 & 339.32 & 15.34 \\
$\Sigma \mathrm{t}_{\mathrm{u}}\left({ }^{\circ} \mathrm{C}\right)$ & 1110.72 & 1080.04 & 1161.50 & 81.46 & 1225.3 & 1195.7 & 1274.1 & 78.3 \\
LGS & 171.78 & 170.09 & 174.53 & 4.43 & 173.98 & 172.37 & 176.62 & 4.25 \\
IHa & 1.61 & 1.41 & 1.70 & 0.29 & 1.87 & 1.64 & 1.97 & 0.33 \\
Ibcv & 6.86 & 6.00 & 7.22 & 1.22 & 7.55 & 6.60 & 7.93 & 1.33 \\
IAOe & 4178.6 & 3994.5 & 4266.0 & 271.4 & 4311.4 & 4118.6 & 4395.7 & 277.1 \\
\hline
\end{tabular}

Climate suitability during the $1980-2013$ period is much higher than the one for the 1961-1979 time period (Table 4): class III of climate suitability has practically disappeared, currently characterizing only $0.2 \%$ of the area; class II has appeared and currently characterizes $99.8 \%$ of the surface, of which $64.4 \%$ is suitable for QWW and 
35.3\% suitable for QWW and RTW, which is an absolutely new type of suitability for this area. This change in suitability is due to the increase in averages of the heliothermic factors, amid a slight decrease in precipitation (Table 5): AAT is of $8.94{ }^{\circ} \mathrm{C}$ in the recent period, higher by $0.47{ }^{\circ} \mathrm{C}$ than the one between 1961-1979; WMT increased by $1.26{ }^{\circ} \mathrm{C}$ reaching the value of $20.72{ }^{\circ} \mathrm{C}$ today; GR is higher by $1.69 \mathrm{kcal} / \mathrm{cm}^{2}$; ASD is also higher by $78.6 \mathrm{~h}$; PP are smaller by $14.1 \mathrm{~mm}$; and IAOe is higher by 133 units, the current value of 4311.4 units placing IAOe in the class of suitability for QWW and RTW.

\section{The viticultural potential and the structure of winegrape varieties during 1961-1979}

The results of the research reveal the existence of three viticultural homogeneous zones in the area, characterized by 6,7 and 8 arp, but whose surface and share in the area radically changed between the 1961 and 2013 as a result of climate change (Table 6).

Table 6. Structure of the viticultural potential for the wine production in the Averești winegrowing region, for the 1961-1979 and 1980-2013 time periods

\begin{tabular}{|c|c|c|c|c|c|c|c|}
\hline \multicolumn{4}{|c|}{ Viticultural potential 1961-1979 } & \multicolumn{4}{|c|}{ Viticultural potential 1980-2013 } \\
\hline \multirow{2}{*}{ Class } & \multirow{2}{*}{$\operatorname{arp}$} & \multicolumn{2}{|c|}{ Share } & \multirow{2}{*}{ Class } & \multirow{2}{*}{ arp } & \multicolumn{2}{|c|}{ Share } \\
\hline & & ha & $\%$ & & & ha & $\%$ \\
\hline \multirow{2}{*}{ III } & 5 & 0.2 & 0.03 & \multirow{2}{*}{ III } & 5 & 0.0 & 0.0 \\
\hline & 6 & 486.2 & 72.3 & & 6 & 161.7 & 24.1 \\
\hline \multirow{2}{*}{ II } & 7 & 176.4 & 26.3 & \multirow{2}{*}{ II } & 7 & 440.1 & 65.5 \\
\hline & 8 & 9.4 & 1.4 & & 8 & 70.4 & 10.5 \\
\hline \multirow{2}{*}{ I } & 9 & 0.0 & 0.0 & \multirow{2}{*}{ I } & 9 & 0.0 & 0.0 \\
\hline & 10 & 0.0 & 0.0 & & 10 & 0.0 & 0.0 \\
\hline \multicolumn{2}{|c|}{ Total } & 672.2 & 100 & & & 672.2 & 100 \\
\hline
\end{tabular}

Between 1961-1979, Avereşti wine-growing region provided mainly WTW, SW, WD and QWW, its viticultural potential having the following structure (Table 6): $0.03 \%$ of the area was characterized by a mean of 5 arp, the viticultural potential for WTW, SW, WD; 72.3\% of the area was characterized by an average of 6 arp, the viticultural potential for WTW, SW, WD and QWW in warm years; $26.3 \%$ of the area was characterized by an average of 7 arp, the viticultural potential for QWW; $1.4 \%$ of the area was characterized by an average of 8 arp, the viticutural potential for QWW and RTW. The viticultural potential for QWW and RTW characterized the slopes with western aspects, while the viticultural potential for WTW, SW, WD characterized the plateau area (Fig. 5a).

The winegrape varieties for the 1961 to 1979 were the ones selected in time by the cultivation of the best adapted varieties. $100 \%$ was represented by varieties for white wines: Fetească albă (FA), Fetească regală (FR), Zghihară de Huşi (Z), Aligoté (AL). Due to the viticultural potential for mainly white wines, the winegrape varieties were well located, with ones for quality white wine such as Feteasca albă and Feteasca regală which were grown on slope areas with QWW potential, and productive ones, such as Zghihară de Huși and Aligoté which were grown in areas with viticultural potential for WTW, SW, WD (Fig. 5b). 


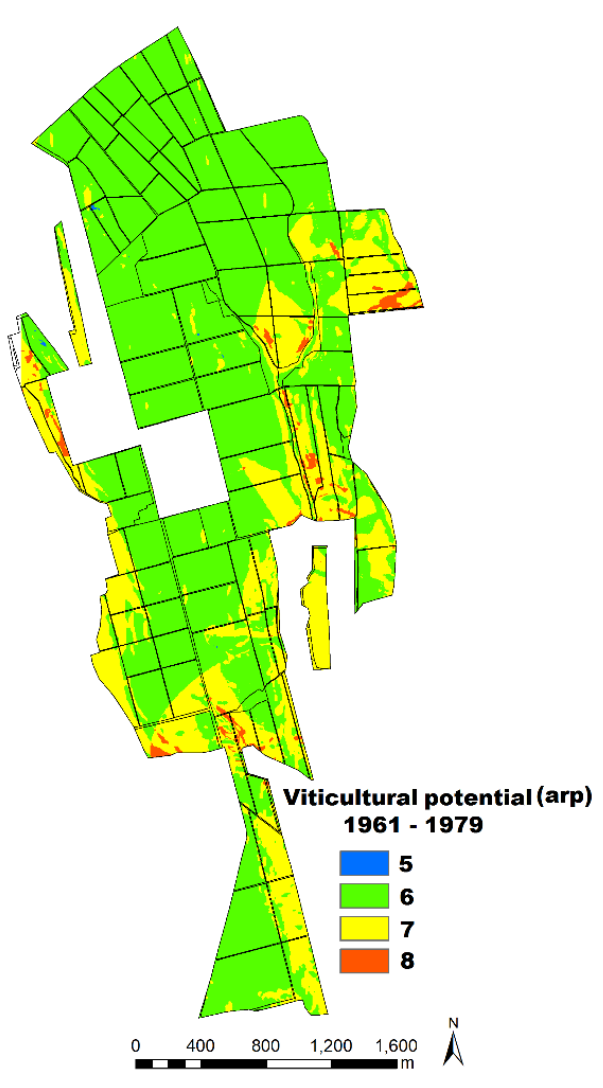

a

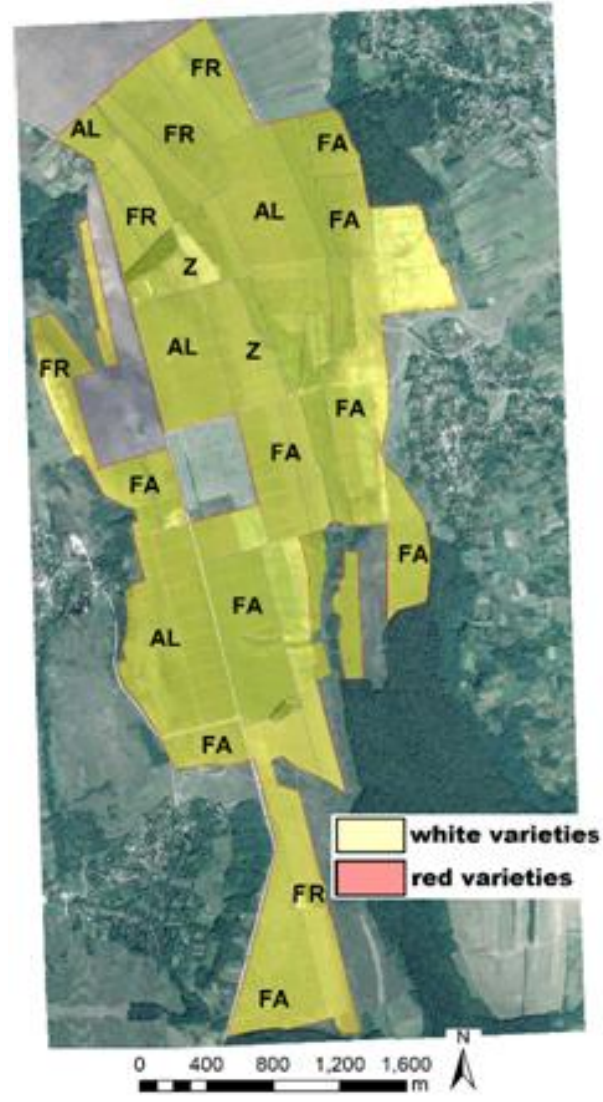

b

Figure 5. Viticultural potential (a) and winegrape varieties (b) of the Avereşti wine-growing region between 1961 and 1979

\section{The viticultural potential between the 1980-2013 and the current structure of the} winegrape varieties grown within the area

According to the data presented in Table 6, the current structure of the viticultural potential of the area is radically different from that of the 1961-1979: the viticultural potential characterized by 5 arp disappeared; the viticultural potential characterized by WTW, SW, WD and QWW in warm years, declined from $72.3 \%$ to $24.1 \%$; the viticultural potential with an average of 7 arp increased from $26.3 \%$ to $65.5 \%$; and the viticultural potential with an average of 8 arp extended from $1.4 \%$ to $10.5 \%$. Basically, after 1980, the wine-growing region became suitable for the QWW and RTW production, unlike the previous period when it was particularly suitable for the WTW, SW and WD production. This new type of viticultural potential, the potential for RTW, characterizes the slopes with western and eastern terrain aspects, where the potential for QWW prevailed in the previous time period, while today's plateau areas, formerly characterized by the WTW, SW and WD potential, have viticultural potential for QWW (Fig. 6a).

The current winegrape varieties of the area, grown after the year 2000, are represented mainly by the international varieties for quality white wines such as Sauvignon (S), Chardonnay (CH), Muscat Ottonel (MO), to which Romanian varieties like Tămâioasa românească (TR), Feteasca albă (FA) and Fetească regală (FR) are 
added (Fig. 6b). For red wines, Cabernet Sauvignon (CS), Merlot (M), Pinot noir (PN) and Romanian variety Fetească neagră (FN) were introduced in the area for the first time (Fig. 6b). In order to capitalize on the new viticultural potential, the Busuioaca de Bohotin (BB) variety, of Mediterranean origin (from the Muscat group), which requires high heliothermal resources and produces aromatic red wines, was also introduced into area. Still, as an anticipated adaptation to climate change, the Rhine Riesling, a late variety that preserve better acidity was introduced in area in the detriment of earlier local variety Feteasca albă, whose acidity can be affected by increasing temperatures in the context of climate change. For the area with WTW and SW potential, the Zghihara de Hussi (Z) variety, with a high production potential has been maintained in cultivation.

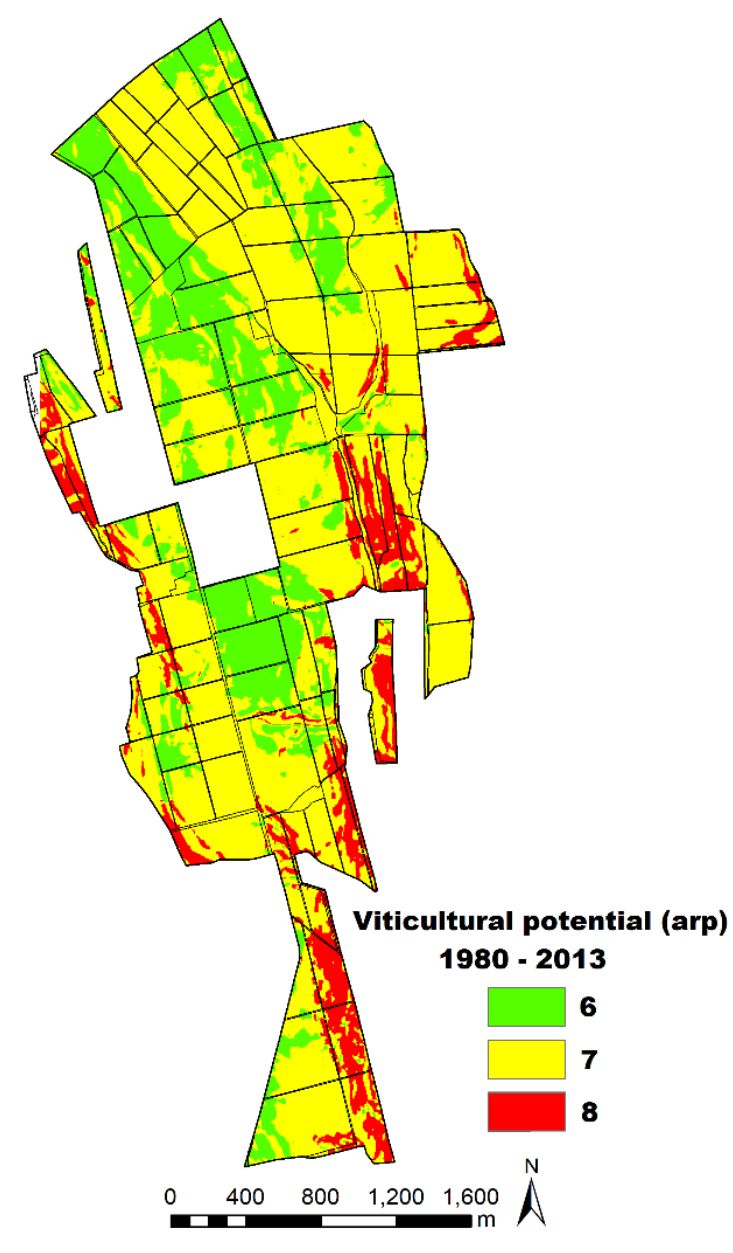

a

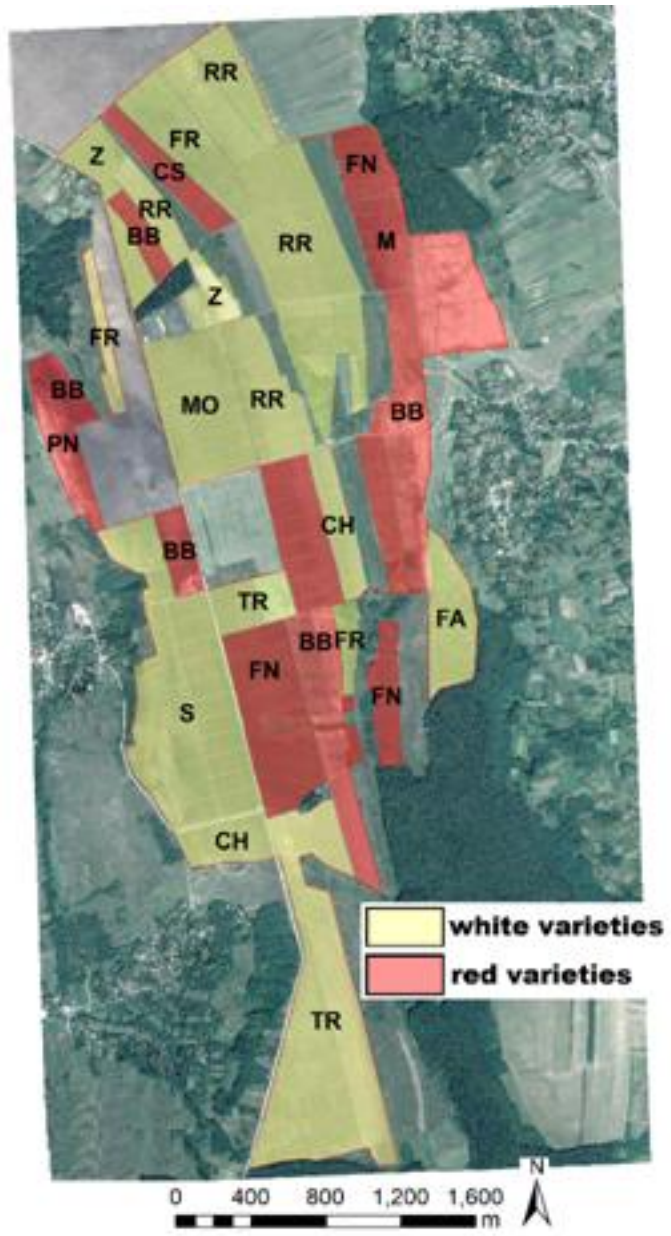

b

Figure 6. Viticultural potential between for the 1980 to 2013 (a) and spatial distribution of current winegrape varieties (b) in the Averești wine-growing region

\section{Analysis of winegrape varieties location in the area}

The location of winegrape varieties introduced in the area after 2000 was based on empirical observations. As a result, white wine varieties were located mainly on flat terrains, while varieties for red wine on slopes and on some flat terrains, appreciated as suitable. 
However, the analysis of the varieties location reveals $15.6 \%$ accuracy for the red wine varieties and $73 \%$ for the white wine varieties (Table 7). About $66 \%$ of the area planted with red wine varieties is located on surfaces with viticultural potential for QWW and $18 \%$, even on surfaces with viticultural potential for WTW, SW and WD. The total area suitable for red wines is of 70.4 ha while the present area growing varieties for red wines is of 220.5 ha, the maximum potential utilization for RTW being of about $32 \%$ compared to $15.6 \%$ realized. The variability analysis reveals the $100 \%$ location of the Cabernet Sauvignon variety in the zone with QWW potential (Fig. 6b); $88.9 \%$ of the Merlot surface is located in the area suitable for QWW and only $3.2 \%$ in the area suitable for RTW; 59.2\% of the Pinot noir surface is located in the area suitable for RTW and only $40.6 \%$ in the area suitable for QWW (Table 7).

Table 7. Framing of the winegrape varieties for red wines newly planted in the area, within the zones with different types of viticultural potential (arp)

\begin{tabular}{|c|c|c|c|c|c|c|c|}
\hline \multirow{2}{*}{$\begin{array}{l}\text { Viticultural } \\
\text { potential } \\
(\operatorname{arp})\end{array}$} & \multicolumn{2}{|c|}{$\begin{array}{c}\text { Framing red and white } \\
\text { winegrape varieties within } \\
\text { suitability classes }(\%)\end{array}$} & \multicolumn{5}{|c|}{$\begin{array}{c}\text { Framing within suitability classes from area }(\%) \text { of the } \\
\text { red winegrape varieties* }\end{array}$} \\
\hline & Red varieties & $\begin{array}{c}\text { White } \\
\text { varieties }\end{array}$ & BB & CS & $\mathbf{F N}$ & $\mathbf{M}$ & PN \\
\hline 6 & 18.0 & 27.7 & 14.1 & 0.0 & 36.5 & 7.9 & 0.2 \\
\hline 7 & 66.4 & 64.2 & 68.8 & 100.0 & 53.4 & 88.9 & 40.6 \\
\hline 8 & 15.6 & 8.1 & 17.1 & 0.0 & 10.1 & 3.2 & 59.2 \\
\hline Total & 100 & 100 & 100 & 100 & 100 & 100 & 100 \\
\hline
\end{tabular}

*BB = Busuioaca de Bohotin $; \mathrm{CS}=$ Cabernet Sauvignon $; \mathrm{FN}=$ Feteasca neagră $; \mathrm{M}=$ Merlot $; \mathrm{PN}=$ Pinot noir

Growing winegrape varieties for red wine in unsuitable areas limits the expression of their quality potential and the possibility to produce quality wines. In the Avereşti area, the lack of suitability for red wines of the zones suitable for WTW, WD, SW and QWW is given by the small values of IAOe $\left(<4300\right.$ units), ASD $(<1450 \mathrm{~h}), \mathrm{TWM}\left(<20^{\circ} \mathrm{C}\right)$, Cly content $(<15 \%)$, Gra $(<10 \%)$ and northern aspects. Obtaining quality red wines is conditioned by the high exposure of the vine canopy to direct solar radiation, higher temperatures and sunshine duration. In wine-growing areas close to the northern limit of vine growing area, these conditions are more difficult to meet, generally occurring on slopes with predominantly southern terrain aspects, well-drained and less fertile soils, and using training systems that ensure the highest percentage of grapevine leaves exposure to direct solar radiation.

\section{Discussion}

The GIS-based multicriteria analysis of the viticultural potential of the Averesti wine-growing region, situated close to the northern limit of grape growing $\left(50^{\circ} \mathrm{N}\right.$ lat.), reveals its increase during the 1961-2013 time period as a consequence of climate change. With the increase of the viticultural potential, changes in specific winegrape varieties have occurred, new winegrape varieties for quality white wines and even varieties for red wine being planted. 
The originality of this study is that the area's viticultural potential has been assessed by taking into account the values of 15 ecological parameters representative of the vineyards' relief, soils and climate, and determinants of the quality and characteristics of wines. This approach ensures the accurate assessment of the viticultural potential, which must include the influence of relief and soils (Irimia et al., 2014). The accuracy of the study is given by: the use of a digital elevation model with a resolution of $5 \times 5$ $\mathrm{m}$; the use of daily temperatures, precipitation and sunshine duration for the period 1961-2013 from the ROCADA database (Dumitrescu and Bîrsan, 2015); the use of pedological data representing the whole viticultural area.

Previous research on the ecological characteristics of the Avereşti wine-growing region revealed the significant spatial variation of the terrain aspect, slope, annual average temperature and sunshine duration (Irimia and Patriche 2009, 2010). The complete evaluation of the viticultural potential has revealed the existence of three homogeneous viticultural zones in the area, whose share changed between 1961 and 2013 as a result of climate change. The cause of the change of the viticultural potential is the climate change that in the region manifests by: AAT increase by $0.47{ }^{\circ} \mathrm{C}$ between 1961 and 2013; TWM increase by $1.26^{\circ} \mathrm{C}$; LGS extension by 2 days between 1961 2013; PP increase by $14.12 \mathrm{~mm}$; and IAOe increase by 132.8 units. The results are consistent with the outcomes of the research on the evolution of temperatures, insolation and precipitation on Romania territory between 1961 to 2010 (Busuioc et al., 2010; Piticar and Ristoiu, 2012; Dumitrescu et al., 2014) and those communicated for this part of Europe by Karl (1998) and Klein Tank and Köhnnen (2003).

The study reveals that climate change not only modifies the vineyards' specific types of wine production. The Avereşti wine-growing region, characterized in the past by a cool, less suitable climate, passed between 1961 and 2013 from mainly WTW, SW and WD viticultural potential to mainly QWW and even RTW viticultural potential. The results are in line with those recorded for the Cotnari wine-growing region, located 200 $\mathrm{km}$ to north, in the same region (Irimia et al., 2017b). So are they in line with the regional developments, the whole of Romania's viticulture being affected by major shifts in climate suitability for the wine production (Bucur and Dejeu, 2016; Irimia et al., 2017a). The results of this study are in accordance with the expected developments for the viticulture of Central and Eastern Europe predicted by Stock et al. (2005), which assessed the evolution of current climate as favoring the expansion of red wine varieties in these areas. In the Averești wine-growing region, the Cabernet Sauvigon, Merlot, Pinot noir, Fetească neagră and Busuioacă de Bohotin red winegrape varieties, not previously existing in the area, were introduced due to the viticultural potential increase determined by climate change.

However, the study demonstrates the need to evaluate the current viticultural potential and to delimit the homogeneous viticultural zones of the wine-growing regions close to the northern limit of vine growing area, that are the beneficiaries of climate change, with a view to the correct zoning of the newly introduced winegrape varieties. In the absence of such an assessment, in the Averești wine-growing region only $15.6 \%$ of the area planted with red wine varieties is located in zones suitable for RTW; about $66 \%$ of the area is located on surfaces suitable for QWW and $18 \%$ on area suitable for WTW, SW, WD. It is expected that in the context of climate change, the area's potential for RTW will increase, but currently it is not at the level where high quality red wines can be obtained. 
The results of the study are especially useful for the Avereşti wine-growing region where the management of vine plantations can be optimized and strategies for capitalizing on the wine production can be elaborated. The study also provides information to researchers and to the entire wine sector on the impact of climate change on the vineyards viticultural potential and their specific wine types.

\section{Conclusions}

The study has shown that the viticultural potential of the Averesti wine-growing region has radically changed in the context of climate change. Evolutions are similar to those found in previous researches on vineyards climate in this geographical region. They are also consistent with the outcomes of other researches on the evolution of viticulture in this part of Europe, namely the increase of the viticultural potential due to the increase of the heliothermal resources. The Averesti wine-growing region evolved between 1961-2013 from the prevalent white table wine production between 1961-1979, to the prevailing potential for quality white wines and red table wines between 1980 and 2013. The new viticultural potential is being exploited in the Averesti wine-growing area by expanding the international varieties for quality white wines and by introducing red wine varieties in culture, an absolutely new wine type production for the area. These developments are specific to wine-growing regions close to the northern limit of vine culture, but this study demonstrates the need to assess the viticultural potential determined by climate change and to delimit the homogeneous viticultural zones in such areas. Although heliothermic resources have increased, they have not yet reached the level at which to obtain high quality red wines. To this the significant spatial variation of the ecological factors is added, which determines the existence in the vineyard area of the homogeneous viticultural zones with different viticultural potential in relation to winegrape varieties requirements. However, due to the frosty winters in the area that still maintain their harshness, further studies on the matching and behaviour of newly introduced wine-grape varieties into Averești wine-growing region are still needed.

Acknowledgements. This work was supported by a grant of the Romanian National Authority for the Scientific Research and Innovation, CNCS/CCCDI-UEFISCDI, project number PN-III-P2-2.1.-BG-20160058, AVEVINPERFORM (http://www.avevinperform.ro/), within PNCDI III.

\section{REFERENCES}

[1] Asselin, C., Barbeau, G., Morlat, R. (2001): Approche de la composante climatique à diverses échelles dans le zonage viticole. - Bull. OIV 74(843/844): 301-318.

[2] Bandoc, G., Prăvălie, R., Patriche, C. V., Dragomir, E., Tomescu, M. (2018): Response of phenological events to climate warming in the southern and south-eastern regions of Romania. - Stoch Environ Res Risk Assess (32)4: 1113-1129. https://doi.org/10.1007/s00477-017-1452-6.

[3] Blanco-Ward, D., Monteiro, A., Lopes, M., Borrego, C., Silveira, C. et al. (2017): Analysis of climate change indices in relation to wine production: A case study in the Douro region (Portugal). - BIO Web of Conferences 9: 01011. doi.org/10.1051/bioconf/20170901011. 
[4] Bucur, M., Dejeu, L. (2016): Research on trends in extreme weather conditions and their effects on grapevine in Romanian viticulture. - Bulletin UASMV Horticulture 73(2): 126-134. DOI: 10.15835/buasvmen-hort:12190.

[5] Busuioc, A., Caian, M., Cheval, S., Bojariu, R., Boroneant, C., Baciu, M., Dumitrescu, A. (2010): Variabilitatea și schimbarea climei în Romania. - Pro Universitaria Press, Bucharest.

[6] Dokoozlian, N. K., Kliewer, W. M. (1996): Influence of light on grape berry growth and composition varies during fruit development. - J Am Soc Hortic Sci 121(5): 869-874.

[7] Dumitrescu, A., Bîrsan, M. V. (2015): ROCADA: a gridded daily climatic dataset over Romania (1961-2013) for nine meteorological variables. - Nat Hazards 78(2): 10451063.

[8] Dumitrescu, A., Bojariu, R., Bîrsan, M. V., Marin, L., Manea, A. (2014): Recent climatic change in Romania from observational data (1961-2013). - Theor Appl Climatol 122: 111-119.

[9] EEA (2017): Global and European temperature, European Environment Agency. https://www.eea.europa.eu/data-and-maps/indicators/global-and-european-temperature-

4/assessment.

[10] Entekhabi, D. (1997): Land Surface Processes: Basic Tools and Concepts, Hydrometeorology and Climatology, p. 3-46. - In: Marani, M., Rigon, R. (eds.). Environmental Dynamics Series, V. Istituto Veneto di Scienze Lettere ed Arti, Venice.

[11] Gaal, M., Moriondo, M., Bindi, M. (2012): Modelling the impact of climate change on the Hungarian wine regions using random forest. - Appl Ecol Environ Res 10: 121-140.

[12] Hijmans, R., Cameron, S. E., Parra, J. L., Jonesc, P. G., Jarvisc, A. (2005): Very high resolution interpolated climate surfaces for global land areas, Int. J. Climatol 25: 19651978.

[13] IPCC (2013): Climate Change 2013: The Physical Science Basis. - In: Stocker, T. F., Qin, D., Plattner, G-K., Tignor. M., Allen, S. K., Boschung, J., Nauels, A., Xia, Y., Bex, V., Midgley. P. M. (eds.) Contribution of Working Group I to the Fifth Assessment Report of the Intergovernmental Panel on Climate Change. Cambridge University Press, Cambridge, UK and New York, NY.

[14] Irimia, L., Patriche, C. V. (2009): Spatial distribution analysis of the ecological factors in the Avereşti wine growing centre - Huşi vineyard. - Agronomical Research in Moldavia 3(139): 33-42.

[15] Irimia, L., Patriche, C. V. (2010): Evaluating the ecological suitability of the vineyards, by using Geographic Information Systems (GIS). - Agronomical Research in Moldavia 1(141): 49-58.

[16] Irimia, L. M., Patriche, C. V., Quenol, H. (2014): Analysis of viticultural potential and deliniation of homogeneous viticultural zones in a temperate climate region of Romania. - J Int Sci Vigne Vin 48(3): 145-167.

[17] Irimia, L. M., Patriche, C. V., Roșca, B. (2017a): Climate change impact on climate suitability for wine production in Romania. - Theor Appl Climatol 131(3-4): 1069-1081. https://doi.org/10.1007/s00704-017-2156-z.

[18] Irimia, L., Patriche, C. V., Quenol, H., Sfîcă, L., Foss, C. (2017b): Shifts in climate suitability for wine production as a result of climate change in a temperate climate wine region of Romania. - Theor Appl Climatol, https://doi.org/10.1007/s00704-017-2033-9.

[19] Jacquet, A., Morlat, R. (1997): Caractérisation de la variabilité climatique des terroirs viticoles en Val de Loire: influence du paysage et des facteurs physiques du milieu. Agronomie 17(9/10): 465-480.

[20] Jones, G. V., Duff, A. A. (2007): The Climate and Landscape Potential for Wine Production in the North Olympic Peninsula Region of Washington. - Open Report to the Clallam Economic Development Council.

[21] Karl, T. R. (1998): Regional Trends and Variations of Temperature and Precipitation. In: Watson, R. T., Zyinyowera, M. C., Moss, R. H. (eds.) The Regional Impacts of 
Climate Change. An Assessment of Vulnerability, pp. 411-437. IPCC, Cambridge University Press.

[22] Kenny, G. J., Harrison, P. A. (1992): The effects of climate variability and change on grape suitability in Europe. - J Wine Res 3(3): 163-183.

[23] Klein Tank, A. M. G., Können, G. P. (2003): Trends in indices of daily temperature and precipitation extremes in Europe. - J Climate 16: 3665-3680.

[24] Kottek, M., Grieser, J., Beck, C., Rudolf, B., Rubel, F. (2006): World map of the Köppen-Geiger climate classification updated. - Meteorologische Zeitschrift 15(3): 259263.

[25] Kovacs, E., Puskas, J., Pozsgai, A. (2017): Positive Effects of Climate Change on the Field of Sopron Wine-Growing Region in Hungary. - In: Karacostas, T., Bais, A., Nastos, P. (eds). Perspectives on Atmospheric Sciences. Springer Atmospheric Sciences. Springer, Switzerland.

[26] Kryza, M., Szymanovski, M., Blas, M. (2015): Observed changes in SAT and GDD and the climatological suitability of the Poland-Germany-Czech Republic transboundary region for wine grapes cultivation. - Theor Appl Climatol 122(1): 207-218.

[27] Le Roux, R., de Rességuier, L., Corpetti, T., Jégou, N., Madelin, M., Van Leeuwen, C., Quénol, H. (2017): Comparison of two fine scale spatial models for mapping temperatures inside winegrowing areas. - Agricultural and Forest Meteorology 247: 159169. DOI: 10.1016/j.agrformet.2017.07.020.

[28] Morlat, R., Bodin, F. (2006): Characterization of viticultural terroirs using a simple field model based on soil depth - II. Validation of the grape yield and berry quality in the Anjou vineyard (France). - Plant Soil 281(1/2): 55-69.

[29] Nemani, R. R., White, M. A., Cayan, D. R., Jones, G. V., Running, S. W., Coughlan, J. C. (2001): Asymmetric warming over coastal California and its impact on the premium wine industry. - Clim Res 19: 25-34.

[30] Nesbitt, A., Kemp, B., Steele, C., Lovett, A., Dorling, S. (2016): Impact of recent climate change and weather variability on the viability of UK viticulture - combining weather and climate records with producers' perspectives. - Aust J Grape Wine Res 22(2): 324335. DOI: 10.1111/ajgw.12215.

[31] Nowlin, J. W., Bunch, R. L. (2016): A model for selecting viticultural sites in the Piedmont Triad region of North Carolina. - International Journal of Applied Geospatial Research 7(3): 38-70. DOI: 10.4018/IJAGR.2016070102.

[32] Patriche, C. V., Irimia, L., Condorachi, D. (2011): Aspects regarding the use of GIS for quantifying climatic factors influencing vineyards suitability. - Scientific Annals of "Alexandru Ioan Cuza" University of Iași - Geografie Series 57: 61-68.

[33] Piticar, A., Ristoiu, D. (2012): Analysis of air temperature evolution in north-eastern Romania and evidence of warming trend. - Carpath J Earth Env 7(4): 91-106.

[34] Quenol, H., Garcia de Cortazar Atauri, I., Bois, B., Sturman, A., Bonnardot, V., Le Roux, R. (2017): Which climatic modeling to assess climate change impacts on vineyards? OENO One 51(2): 91-97. https://doi.org/https://doi.org/10.20870/oenoone.2016.0.0.1869.

[35] Riou, C., Carbonneau, A., Becker, N., Calo, A., Costacurta, A., Castro, R. (1994): Le determinisme climatique de la maturation du raisin: application au zonage de la teneur en sucre dans la Communaute Europeenne. - Office des Publications Officielles des Communautes Europeennes, Luxembourg.

[36] Seguin, G. (1986): 'Terroirs' and pedology of wine growing. - Experientia 42(8): 861873.

[37] Stock, M., Gerstengarbe, F. W., Werner, P. C. (2005): Reliability of climate change impact assessments for viticulture. - Acta Horticulturae 689: 29-40.

[38] Tomasi, D., Gaiotti, F., Jones, G. V. (2013): The Power of the Terroir: The Case Study of Prosecco Wine. - Springer Press, Basel, Switzerland. 
[39] Urcan, D. E., Lung, M. L., Giacosa, S., Torchio, F., Ferrandino, A., Vincenzi, S., Río Segade, S., Pop, N., Rolle, L. (2016): Phenolic substances, flavor compounds, and textural properties of three native Romanian wine grape varieties. - Int J Food Prop 19(1): 76-98.

[40] van Leeuwen, C., Seguin, G. (2006): The concept of terroir in viticulture. - Journal of Wine Research 171: 1-10.

[41] Winkler, A. J., Cook, J. A., Kliewer, W. M., Lieder, L. A. (1974): General Viticulture. Univ of California Press, Berkeley, California.

[42] Wolkovich, E. M., García de Cortázar-Atauri, I., Morales-Castilla, I., Nicholas, K. A., Lacombe, T. (2018): From Pinot to Xinomavro in the world's future wine-growing regions. - Nature Climate Change 8(1): 29-37. DOI: 10.1038/s41558-017-0016-6. 